\title{
ŠKOLSKA PEDAGOGIJA U STUDIJSKIM PROGRAMIMA OSNOVNIH AKADEMSKIH STUDIJA PEDAGOGIJE - ANALIZA SILABUSA ${ }^{1}$
}

\section{Zorica Stanisavljević Petrović², Marija Marković, Anastasija Mamutović}

Univerzitet u Nišu, Filozofski fakultet, Departman za pedagogiju

\begin{abstract}
Apstrakt: Rad predstavlja uporednu analizu silabusa nastavnog predmeta Školska pedagogija u studijskim programima za pedagogiju na fakultetima filozofske orijentacije u Nišu, Nikšiću i Skoplju. Cilj rada je da se ispita usaglašenost silabusa za studijski predmet Školska pedagogija na osnovnim akademskim studijama pedagogije na datim fakultetima. Osnovna tehnika istraživanja je analiza sadržaja silabusa za predmet Školska pedagogija. Uporedna analiza urađena je na osnovu sledećih jednica analize: status predmeta, ciljevi, sadržaji predmeta, metode učenja, način ocenjivanja, ishodi učenja i literatura. Rezultati istraživanja pokazali su da u odnosu na ispitivane jedinice analize postoje razlike i da stepen usaglašenosti sadržaja silabusa za predmet Školska pedagogija varira u odnosu na ispitivane oblasti. Najviši stepen usaglašenosti ostvaren je u domenu ciljeva i sadržaja predmeta, dok je najmanja usaglašenost evidentirana na polju korišćene literature. Implikacije sprovedenog istraživanja mogu biti osnova za promene u silabusu za predmet Školska pedagogija u narednoj reakreditaciji studijskog programa za pedagogiju na Filozofskom fakultetu u Nišu.
\end{abstract}

Ključne reči: školska pedagogija, studijski programi, silabusi, usaglašenost, analiza

\section{Uvod}

Promene u visokom obrazovanju zahtevaju kontinuirano praćenje novih saznanja i obogaćivanje programskih sadržaja u cilju što kvalitetnijeg obrazovanja studenata. U tom kontekstu veoma je važno stalno preispitivanje studijskih programa, njihovo menjanje i usaglašavanje sa novim aktuelnim potrebama. Reforma visokog obrazovanja u Srbiji ističe zahtev za usklađivanjem sa evropskim obrazovnim standardima, te je stoga u procesu akreditacije studijskih programa veoma važna usaglašenost kako sa programima razvijenih evropskih zemalja, tako i sa programima država u okruženju.

\footnotetext{
${ }^{1}$ Rad je nastao kao rezultat rada na projektu broj 183/1-16-8-01, pod nazivom Unapređivanje i osavremenjavanje osnovnih akademskih studija pedagogije, finansiranom od strane Filozofskog fakulteta u Nišu.

${ }^{2}$ zorica.stanisavljevic.petrovic@filfak.ni.ac.rs
} 
Studijski programi za pedagogiju u skladu su sa savremenim zahtevima reforme visokog obrazovanja, teže ka usklađivanju sa evropskim standardima, ali istovremeno teže da zadovolje i aktuelne potrebe savremenih škola kao vaspitno obrazovnih institucija. Saglasno tome, svaka nova reakreditacija studijskog programa praćena je inovacijama, bilo da je reč o uvođenju novih nastavnih predmeta ili obogaćivanju sadržaja u predmetima koji već postoje u studijskom programu. Imajući u vidu da u školama dolazi do značajnih promena, javlja se potreba za preispitivanjem sadržaja nastavnog predmeta Školska pedagogija i njegove usklađenosti sa sličnim programima iz okruženja.

\section{Metodološki okvir istraživanja}

Poznato je da nastavni predmet Školska pedagogija zauzima značajno mesto u studijskim programima za pedagogiju. Školska pedagogija se najčešće određuje kao pedagoška disciplina koja se bavi proučavanjem teorijskih i praktičnih problema vaspitno-obrazovnog procesa koji se ostvaruje u školi ili putem škole (Đorđević i Ničković, 1991; Janković i Rodić, 2007; Leksikon obrazovnih termina, 2014; Pedagoška enciklopedija 2, 1989; Pedagoški leksikon, 1996). Kao studijski predmet Školska pedagogija se proučava na univerzitetima u Srbiji, i to na Filozofskom fakultetu u Novom Sadu, Beogradu i Kosovskoj Mitrovici u okviru studijskih programa za pedagogiju i na učiteljskim ili pedagoškim fakultetima na smerovima namenjenim obrazovanju budućih učitelja (Marković i Stanisavljević Petrović, 2017). U studijskim programima ovih fakulteta, sadržaji predmeta Školska pedagogija, kao i druge važne informacije o samom predmetu mogu se naći u posebnom dokumentu - silabusu za predmet Školska pedagogija.

Predmet istraživanja je sagledavanje načina na koji je studijski predmet Školska pedagogija predstavljen u silabusima studijskih programa za pedagogiju kod nas i u državama iz okruženja. Cilj istraživanja je ispitivanje usaglašenosti u sadržajima silabusa za predmet Školska pedagogija u studijskim programima za pedagogiju na Filozofskom fakultetu Univerziteta „Kiril i Metodij“ u Skoplju, Univerziteta Crne Gore u Nikšiću i Univerziteta u Nišu. Metod istraživanja je analiza sadržaja silabusa za predmet Školska pedagogija, a osnovne jedinice analize su elementi silabusa, i to: status predmeta, ciljevi, sadržaji predmeta, metode učenja, način ocenjivanja, ishodi učenja, literatura. Polazna hipoteza istraživanja je da postoji usaglašenost $u$ silabusima za predmet Školska pedagogija na studijskim programima za pedagogiju na filozofskim fakultetima Univerziteta u Skoplju, Nikšiću i Nišu. Uzorak istraživanja činili su silabusi aktuelnih studijskih programa za pedagogiju: Studijski i predmetni program za pedagogiju, prvi ciklus studija na Filozofskom fakultetu u Skoplju iz 2018/2019. godine (Студијска и предметна програма по Педагогија од I (прв) циклус на студии на Филозофски факултет, 2018/2019), Studijski program osnovnih studija za pedagogiju Filozofskog fakulteta u Nišu iz 2017. godine (ECTS Katalog sa ishodima učenja, 2017: 1) i Studijski program za pedagogiju iz 2014. na Filozofskom fakultetu u Nišu (Tabela 5.2). 


\section{Prikazi silabusa za predmet Školska pedagogija}

\subsection{Nastavni predmet Školska pedagogija na Filozofskom fakultetu u Skoplju}

Nastavni predmet Školska pedagogija se izučava na grupi za pedagogiju u okviru osnovnih akademskih studija na Filozofskom fakultetu u Skoplju tokom treće godine studije, tačnije u petom semestru. Na ovom fakultetu predmet Školska pedagogija je u statusu izbornih predmeta i zajedno sa drugim srodnim predmetima (ICT u nastavi 2+1 i Školska dokimologija 2+1) pruža podršku razvoju kompetencija budućih pedagoga za rad u školskim institucijama. Na Filozofskom fakultetu u Skoplju nastavni predmet Školska pedagogija je zastupljen sa 2 časa predavanja i jednim časom vežbi i nosi 4 kredita (ESPB boda). Ciljevi predmeta definisani su kroz kompetencije koje studenti treba da steknu tokom studiranja i odnose se na osnovna znanja koja studenti treba da steknu o „, tradicionalnim i savremenim modelima pedagoške delatnosti u školi i o faktorima i nosiocima vaspitno-obrazovne delatnosti, i da se osposobe za planiranje, realizaciju i vrednovanje pedagoškog rada u školi“ (Студијска и предметна програма по Педагогија од I (прв) циклус на студии на Филозофски факултет, 2018/2019: 87).

Sadržaji silabusa za predmet Školska pedagogija na ovom fakultetu obuhvataju 15 tematskih jedinica: Školska pedagogija u sistemu pedagoških nauka, Osnovne etape u razvoju škole; Vrste škola; Tradicionalni i savremeni modeli organizacije u školi; Osnovi koncepcije savremene škole; Vaspitno-obrazovne aktivnosti u školi; Škola i njeno okruženje; Direktor kao pedagoški rukovodilac; Nastavnik kao pedagoški faktor; Stručni saradnici u školi; Školski pedagog kao stručni radnik u školi; Tretman učenika u školi; Škola i roditelji; Praćenje i vrednovanje pedagoškog rada u školi; Pedagoška evidencija i dokumentacija (Студијска и предметна програма по Педагогија од I (прв) циклус на студии на Филозофски факултет, 2018/2019: 88).

Pored sadržaja predmeta u silabusu su jasno definisane metode učenja, koje pored predavanja obuhvataju i druge oblike angažovanja studenata poput diskusija, samostalnih prezentacija, praktičnih vežbi, radionica, konsultacija, samostalnog učenja. U silabusu su predviđeni načini praćenja i vrednovanja, napredovanja i uspešnosti studenata, posete osnovnim i srednjim školama i drugim institucijama vaspitno-obrazovnog i naučno-istraživačkog karaktera.

Način ocenjivanja studenata sastoji se od testova, koji mogu nositi do 70 bodova, seminarskih radova, projekata, prezentacija za koje je predviđeno do 15 bodova i aktivnosti i angažovanja studenata koje, takođe, mogu nositi maksimalno 15 bodova.

U silabusu za Školsku pedagogiju na ovom fakultetu predviđena je obavezna i dopunska literatura. Obaveznu literaturu čine tri knjige: Školska pedagogija - interna skripta (Стојановска, 2017); priručnik Upravljanje dinamičnom školom, koji je izdao Biro za razvoj obrazovanja u Skoplju (Петковски и Алексова, 2004) i Indikatori za kvalitet rada u školama u izdanju Ministarstva za obrazovanje i nauku i Državnog prosvetnog inspektorata iz 2009. godine. Dopunska literatura obuhvata tri knjige: Priručnik za razvojno planiranje u školama (Петковски и Трајковска, 2004); udžbenik Školska pedagogija (Vrcelj, 2000) i zbirku tekstova pod nazivom Školska pedagogija (Ilić i sar., 2008). 


\subsection{Nastavni predmet Školska pedagogija na Filozofskom fakultetu u Nikšiću}

Na Univerzitetu Crne Gore, na Filozofskom fakultetu u Nikšiću nastavni predmet Školska pedagogija je obavezni predmet na studijskom programu za pedagogiju, koji se realizuje tokom trećeg semestra, sa fondom od 3 časa predavanja i dva časa vežbi i nosi 7 bodova. Prema ECTS katalogu sa ishodima učenja, cilj ovog predmeta je „Pripremanje i osposobljavanje studenata za potpunije razumevanje školskog vaspitanja u cilju njegovog unapređenja; Neposredno osposobljavanje studenata za proučavanje i unapređenje vaspitno-obrazovnog rada na nivou vaspitno-obrazovne institucije kao celine, te na nivou razreda i odeljenja (ECTS Katalog sa ishodima učenja, 2017: 1). Kao metode nastave i učenja predviđena su predavanja, konsultacije, debate, pisani eseji na zadatu temu, a u svrhu evaluacije testovi i završni ispit.

Sadržaji predmeta obuhvataju sledeće teme: Školska pedagogija kao naučna disciplina; Analiza sistema pedagoških disciplina i položaja školske pedagogije u istom; Pojava i razvoj škole; Osvrt na istorijski razvoj škole; Značaj i specifičnosti školskog vaspitanja i obrazovanja. Analiza ključnih pedagoških pojmova (vaspitanje, obrazovanje, nastava; Kritika škole i školskog načina vaspitanja; Analiza ključnih elemenata kritike škole i povezivanje sa aktuelnim stanjem u školama; Vrste i tipovi škola; Diskusija o karakteristikama osnovne i srednje (opšteobrazovne i stručne) škole; Škola i školski sistem, savremena organizacija rada škole; Struktura obrazovnog sistema Crne Gore sa posebnim osvrtom na školski sistem; Struktura vaspitno-obrazovne delatnosti škole; Položaj učenika u školi; Analiza položaja učenika u školi; Uloga i zadaci nastavnika u školskom radu; Metodika vaspitnog delovanja u savremenoj školi; Škola i država - kako demokratizovati školu; Uloga i zadaci školskog pedagoga; Analiza osnovnih područja rada školskog pedagoga; Škola i njeno okruženje (ECTS Katalog sa ishodima učenja, 2017: 1).

U okviru ovog predmeta obaveze studenata su da pohađaju nastavu, da učestvuju u debatama, pripremi i prezentaciji eseja i da urade dva testa. U okviru silabusa za Školsku pedagogiju predviđeni su i ishodi predmeta. Naime, očekuje se da će nakon položenog ispita studenti biti u mogućnosti da: Opišu i objasne osnovne pojmove i teorije školske pedagogije; Analiziraju školski sistem i mesto škole u tom sistemu; Da objasne nastanak i razvoj škola, krizu i kritiku škole, kao i alternativne škole; Imenuju strukturu vaspitno-obrazovne delatnosti škole; Povežu i obrazlože ulogu nastavnika i učenika u školi; Razlikuju demokratske od etatističkih vidova upravljanja školom (ECTS Katalog sa ishodima učenja, 2017: 2).

Za realizaciju predmeta predviđena je literatura koja se sastoji od 9 knjiga i to: Pedagogija - glava III i IV (Trnavac i Đorđević, 1992); Pedagogija II - poglavlje o školi (Krneta i sar., 1968); udžbenik Školska pedagogija I i II (Trnavac, 2005); Organizacija i rukovođenje školom (Vilotijević, 1993); Školska i porodična pedagogija (Kačapor i Vilotijević, 2005); Školska pedagogija (Ilić i sar., 2008); Škola i kultura (Ikor, 1980); Škola koju su osnovali učenici (Jorgensen, 1977) i Interaktivna nastava (Roeders, 2003). 


\subsection{Nastavni predmet Školska pedagogija na Filozofskom fakultetu u Nišu}

Na Departmanu za pedagogiju Filozofskog fakulteta u Nišu predmet Školska pedagogija je sastavni deo studijakog programa na osnovnim akademskim studijama. U statusu je obaveznog predmeta, a realizuje se u V semestru i nosi 5 ESPB bodova. Cilj predmeta je „Razumevanje i usvajanje teorijskih znanja i shvatanje zakonitosti u organizaciji i funkcionisanju škole kao vaspitno-obrazovne institucije. Upoznavanje sa nastavnim i vannastavnim aktivnostima u školi, načinima njihovog organizovanja i mogućnostima promena“" (Studijski program za pedagogiju 2014, Tabela 5.2).

Sadržaji ovog studijskog predmeta organizovani su u 15 tematskih celina: Uvodni čas - upoznavanje studenata sa ciljevima i sadržajem predmeta, načinom realizacije, organizacijom, metodama rada i načinom polaganja ispita; Školska pedagogija kao naučna disciplina i studijski predmet; Teorije škole; Škola kao sistem; Socijalni sistem škole; Organizacija rada i života škole; Konstitutivne komponente škole - nastavnik; Učenici - opterećenost, školski uspeh, odnos nastavnika i učenika; Struktura i organizacija vaspitno-obrazovnih aktivnosti škole; Produženi i celodnevni boravak učenika, vaspitna vrednost škole u prirodi; Dopunski, dodatni i korektivno pedagoški rad; Otvorenost škole prema okruženju - škola i društvo, škola i svet rada, škola i crkva; Razvoj partnerstva škole i porodice; Rukovođenje i upravljanje školom; Škola kao predmet kritike. Pored obaveznih predavanja metode učenja na vežbama obuhvataju analizu, tumačenje i diskusiju, odbrane seminarskih radova, prezentacije projekata i istraživanja iz školske prakse.

Obavezna literatura obuhvata odgovarajuće delove iz sledećih pet knjiga: udžbenik Školska pedagogija (Janković i Rodić, 2007); Promene u školskom sistemu u Srbiji (Stanisavljević Petrović i Vidanović, 2012): Učenik i nastavnik u obrazovnom procesu (Havelka, 2000); Školska pedagogija (Trnavac, 2005) i Škola kao sistem (Hebib, 2009).

Evaluacija znanja obuhvata aktivnost $\mathrm{u}$ toku predavanja, prezentacije individualnih i grupnih projekata ili seminarskih radova i jedan test. Ispit se sastoji od pisanog dela koji nosi 20 poena i usmenog na kome se može postići maksimalno 30 poena.

Ishod predmeta je definisan i odnosi se na „razvoj profesionalnih kompetencija u oblasti vaspitno-obrazovnog rada u školi: Razvoj kritičkog mišljenja o aktuelnim problemima škole u cilju ispitivanja, menjanja i razvoja školske prakse. Razvoj sposobnosti argumentovane diskusije, izlaganja i prezentacije“ (Studijski program za pedagogiju, 2014, Tabela 5.2).

\section{Analiza silabusa sa diskusijom}

U Tabeli 1 prikazani su osnovni podaci iz analiziranih silabusa o predmetu Školska pedagogija. Na osnovu prikazanih podataka može se konstatovati da postoje razlike u fondu časova za predmet Školska pedagogija jedino u silabusu studijskog 
programa za pedagogiju koji se realizuje na Filozofskom fakultetu u Skoplju, gde je ovaj predmet zastupljen sa 2 časa predavanja i jednim časom vežbi, dok je u ostala dva silabusa fond časova ujednačen i zastupljen sa 2 časa predavanja i dva časa predviđenih za realizaciju vežbi. U odnosu na godinu studija i semestar u kome se predmet realizuje takođe su prisutne razlike. Dok se na Filozofskim fakultetima u Skoplju i Nišu predmet Školska pedagogija realizuje na trećoj godini studija, odnosno u V semestru, na Filozofskom fakultetu u Nikšiću realizacija ovog predmeta je zastupljena na drugoj godini studija, odnosno u III semestru. Zanimljivo je da u analiziranim silabusima postoje razlike u odnosu na broj kredita koji nosi studijski predmet Školska pedagogija. Naime, iz Tabele 1 se može videti da na Filozofskom fakultetu u Skoplju ovaj predmet nosi 4 kredita, na Filozofskom fakultetu u Nikšiću 7 kredita, dok je Filozofskom fakultetu u Nišu zastupljen sa 5 kredita. Za razliku od toga, postoji potpuna ujednočenost $\mathrm{u}$ odnosu na uslove pohađanja predmeta, odnosno ni u jednom od analiziranih silabusa nije predveđen uslov u smislu prethodno položenih ispita, za realizaciju sadržaja predmeta Školska pedagogija.

\section{Tabela 1. Osnovni podaci o predmetu Školska pedagogija}

\begin{tabular}{|c|c|c|c|c|c|}
\hline Silabusi & Broj časova & Godina & Semestar & Broj kredita & Uslovljenost \\
\hline Skoplje & $2+1$ & III & V & 4 & Nema \\
\hline Nikšić & $2+2$ & II & III & 7 & Nema \\
\hline Niš & $2+2$ & III & V & 5 & Nema \\
\hline
\end{tabular}

Pored elemenata prikazanih u Tabeli 1, analiza silabusa za predmet Školska pedagogija urađena je i u odnosu na sledeće jedinice analize: status predmeta, ciljevi, sadržaji predmeta, metode učenja, način ocenjivanja, ishodi učenja i literatura.

\subsection{Status predmeta Školska pedagogija u studijskim programima za pedagogiju}

$\mathrm{Na}$ osnovu pregleda studijskih programa za pedagogiju na Filozofskim fakultetima u Skoplju, Nikšiću i Nišu, može se konstatovati da postoje razlike u statusu predmeta Školska pedagogija. Naime, na fakultetima u Nikšiću i Nišu u studijskim programima za pedagogiju predmet Školska pedagogija ima status obaveznog predmeta, dok je u studijskom programu za pedagogiju u Skoplju status ovog predmeta izborni. Međutim, potrebno je pomenuti da je u studijskom programu za pedagogiju u Skoplju predmet Školska pedagogija podržan sa još dva izborna predmeta na kojima se realizuju sadržaji vezani za školsko vaspitanje i obrazovanje i to sa predmetima ICT u nastavi $(2+1)$ i Školska dokimologija $(2+1)$.

\subsection{Ciljevi predmeta Školska pedagogija u silabusima}

$\mathrm{Na}$ osnovu pregleda ciljeva predmeta Školska pedagogija u analiziranim silabusima primetna je orijentacija ka pripremanju i osposobljavanju studenata pedagogije za unapređivanje škole kao institucije i školskog rada. Naime, u svim silabusima je prisutna namera osposobljavanja studenata za planiranje, realizaciju i vrednovanje 
pedagoškog rada u školi, što je vrlo eksplicitno iskazano u ciljevima predmeta u silabusu studijskog programa u Skoplju. Slično tome, u silabusu za Školsku pedagogiju na Filozofskom fakultetu u Nikšiću ukazuje se na potrebu za pripremanjem i osposobljavanjem studenata za proučavanje i unapređivanje vaspitno-obrazovnog rada u školi. U silabusu za predmet Školska pedagogija u Nišu cilj predmeta je konkretnije određen kao upoznavanje studenata sa nastavnim i vannastavnim aktivnostima u školi, što se svakako odnosi na pripremanje za uključivanje u rad škole i uvođenje promena u smislu razvoja i unapređivanja postojeće prakse. Primetno je da postoje i sličnosti u definisanju ciljeva predmeta u silabusima za Školsku pedagogiju u Nišu i Nikšiću u delu koji se odnosi na potpunije razumevanje školskog vaspitanja i funkcionisanja škole kao vaspitno-obrazovne institucije. Naime, u okviru ova dva silabusa razumevanje teorijskih znanja i školskog vaspitanja su ključni elementi u ciljevima predmeta Školska pedagogija. Pored evidentnih sličnosti u definisanju ciljeva predmeta Školska pedagogija, mogu se uočiti i neke razlike, koje su minimalne, ali dovoljne da čine specifičnost svakog od analiziranih programa. Primera radi u odnosu na analizirane ciljeve predmeta može se izdvojiti cilj koji se odnosi na faktore i nosioce vaspitno-obrazovne delatnosti u školi, koji je eksplicitno dat jedino u silabusu za Školsku pedagogiju studijskog programa u Skoplju. Premda se uvidom u sadržaje silabusa može konstatovati da su ovi sadržaji prisutni u svim analiziranim silabusima (reč je o nastavnicima, učenicima i drugim školskim akterima), u okviru ciljeva oni su zastupljeni samo u silabusu predmeta Školska pedagogija na Filozofskom fakultetu u Skoplju. U okviru ciljeva predmeta Školska pedagogija na Filozofskom fakultetu u Nikšiću, pored nivoa škole, kao institucije u celini, ukazuje se i na potrebu za pripremanjem studenata za vaspitno-obrazovni rad na nivou razreda i odeljenja. U silabusu za predmet Školska pedagogija na Filozofskom fakultetu u Nišu može se izdvojiti potreba za potpunijim upoznavanjem strukture aktivnosti škole, među kojima se izdvajaju nastavne i vannastavne aktivnosti.

Dakle, na osnovu pregleda ciljeva može se konstatovati da postoji visoka usaglašenost u definisanju ciljeva predmeta Školska pedagogija u silabusima koji su analizirani.

\subsection{Sadržaji predmeta Školska pedagogija}

Na osnovu analize silabusa sva tri studijska programa može se utvrditi da postoji visok stepen usaglašenosti u sadržajima predmeta Školska pedagogija. Najveći broj tema predloženih za realizaciju je veoma sličan, tako da se može konstatovati da postoji usaglašenost u tematskom smislu. U cilju boljeg pregleda i jasnijeg uvida u sadržaje predmeta Školska pedagogija u sva tri analizirana programa, sve teme su podeljene u 4 celine: (1) Prva celina obuhvata specifičnosti Školske pedagogije kao naučne discipline i/ili nastavnog predmeta; (2) Druga celina obuhvata teme koje se odnose na školu kao vaspitno-obrazovnu instituciju; (3) Treća celina se odnosi na ključne aktere u školi; (4) Četvrta celina obuhvata teme vezane za odnos škole i okruženja.

U okviru prve celine - Specifičnosti Školske pedagogije kao naučne discipline i/ili nastavnog predmeta, u sva tri analizirana silabusa prisutne su teme koje se odno- 
se na pojam i predmet Školske pedagogije i njeno mesto u sistemu pedagoških disciplina. U silabusu Filozofskog fakulteta u Skoplju u okviru prve celine prisutna je samo jedna tema koja se odnosi na postavljenost Školske pedagogije u sistemu pedagoških nauka: Školska pedagogija u sistemu pedagoških nauka. U silabusu Filozofskog fakulteta u Nikšiću u okviru prve celine zastupljene su sledeće teme: Školska pedagogija kao naučna disciplina; Analiza sistema pedagoških disciplina i položaja školske pedagogije u istom, dok se u silabusu za Školsku pedagogiju Filozofskog fakulteta u Nišu izučava Školska pedagogija kao naučna disciplina i studijski predmet.

U okviru druge celine - Škola kao vaspitno-obrazovna institucija, u silabusu Filozofskog fakulteta u Skolju zastupljene su sledeće teme: Osnovne etape u razvoju škole; Vrste škola, tradicionalni i savremeni modeli organizacije škola; Osnove za koncepciju savremene škole i vaspitno-obrazovne aktivnosti u školi. U silabusu Filozofskog fakulteta u Nikšiću u okviru druge celine predviđene su sledeće teme: Pojava i razvoj škole; Osvrt na istorijski razvoj škole; Značaj i specifičnosti školskog vaspitanja i obrazovanja. Analiza ključnih pedagoških pojmova (vaspitanje, obrazovanje, nastava); Kritika škole i školskog načina vaspitanja; Analiza ključnih elemenata kritike škole i povezivanje sa aktuelnim stanjem u školama; Vrste i tipovi škola; Diskusija o karakteristikama osnovne i srednje (opšteobrazovne i stručne) škole; Škola i školski sistem, savremena organizacija rada škole; Struktura obrazovnog sistema Crne Gore sa posebnim osvrtom na školski sistem; Struktura vaspitno-obrazovne delatnosti škole. U silabusu Filozofskog fakulteta u Nišu u okviru druge celine uključene su sledeće teme: Teorije škole; Škola kao sistem; Organizacija rada i života škole; Struktura i organizacija vaspitno-obrazovnih aktivnosti škole; Produženi i celodnevni boravak učenika, vaspitna vrednost škole u prirodi; Dopunski, dodatni i korektivno pedagoški rad; Škola kao predmet kritike.

Treća celina, koja se odnosi na ključne aktere $u$ školi, takođe je zastupljena u svim analiziranim silabusima: U silabusu Filozofskog fakulteta u Skoplju, u okviru ove celine uključene su sledeće teme: Direktor kao pedagoški rukovodilac; Nastavnik kao pedagoški faktor, Stručni saradnici u školi i Tretman učenika u školi. U silabusu Filozofskog fakulteta u Nikšiću u okviru treće celine zastupljene su sledeće teme: Položaj učenika u školi; Analiza položaja učenika u školi; Uloga i zadaci nastavnika u školskom radu. Na Filozofskom fakultetu u Nišu u silabusu za predmet Školska pedagogija u okviru druge celine predviđene su sledeće teme: Socijalni sistem škole; Konstitutivne komponenete škole - nastavnik; Učenici - opterećenost, školski uspeh, odnos nastavnika i učenika; Rukovođenje i upravljanje školom.

Škola i okruženje je naziv četvrte celine u okviru koje su analizirane teme u silabusima za Školsku pedagogija na Filozofskom fakultetima u Skoplju, Nikšiću i Nišu. Na Filozofskom fakultetu u Skoplju u okviru ove celine zastupljene su dve teme, od kojih je šire postavljena i odnosi se na odnos škole prema društvenoj sredini: Škola i okruženje, i druga koja obuhvata pitanja vezana za saradnju škole i porodice: Škola i roditelji. U silabusu Filozofskog fakulteta u Nikšiću pitanjima odnosa škole i okruženja je posvećene su dve teme: Škola i njeno okruženje i Škola i država - kako demokratizovati školu, dok su u silabusu Filozofskog fakulteta u Nišu zastupljene sledeće teme: Otvorenost škole prema okruženju - škola i društvo, škola i svet rada, škola i crkva; Razvoj partnerstva škole i porodice. 
Pored niza sličnosti u sadržajima silabusa za predmet Školska pedagogija, potrebno je pomenuti da postoje i neke specifične teme, koje su karakteristične za svaki od analiziranih silabusa. Primera radi, jedino u silabusu za Školsku pedagogiju Filozofskog fakulteta u Skoplju u okviru silabusa su predviđene teme koje se odnose na praćenje i vrednovanje školskog rada i dokumentovanja u školi: Praćenje i vrednovanje pedagoškog rada u školi i Pedagoška evidencija i dokumentacija. Imajući u vidu da je reč o temama koje su u uskoj vezi sa kvalitetom škole i njenim razvojem, proučavanje ovih sadržaja za buduće pedagoge može biti višestruko korisno. U tom kontekstu moguće je promišljati o zastupljenosti pomenutih tema u silabusu za Školsku pedagogiju u narednom akreditacionom ciklusu.

Slično tome, na Filozofskom fakultetu u Nikšiću, za razliku od ostala dva silabusa, prisutne su teme koje se odnose na rad pedagoga u školi: Uloga i zadaci školskog pedagoga i Analiza osnovnih područja rada školskog pedagoga.

\subsection{Metode učenja}

U analiziranim silabusima za Školsku pedagogiju u odnosu na metode učenja primetan je visok stepen usaglašenosti. Naime, na osnovu analize može se konstatovati da dominiraju metode aktivnog učenja koje pored obaveznih predavanja i vežbi, obuhvataju diskusije, radionice, samostalni rad studenata u vidu izrade prezentacija ili projekata. U silabusu za Školsku pedagogiju Filozofskog fakulteta u Skoplju su date najraznovrsnije i najdetaljije opisane metode učenja. Takođe, jedino u ovom silabusu su previđene aktivnosti vezane za praktični rad studenata. U ovom silabusu u okviru metoda učenja zastupljena su predavanja, diskusije, samostalne studentske prezentacije, praktične vežbe, radionice, konsultacije, samostalno učenje studenata, praćenje napredovanja i uspeha studenata, posete osnovnim i srednjim školama i drugim naučno-istraživačkim i vaspitno-obrazovnim institucijama. U silabusu za Školsku pedagogiju na Filozofskom fakultetu u Nikšiću, kao osnovne metode učenja izdvojena su predavanja i debate, a pred toga izdvaja se pripremanje eseja na zadatu temu iz oblasti sadržaja predmeta, kao i učenje za testove i završni ispit i konsultacije. U delu silabusa Filozofskog fakulteta u Nišu koji se odnosi na metode učenja, navodi se da je zastupljen interaktivni pristup, prezentacije, diskusija, debate i timski rad studenata.

\subsection{Način ocenjivanja studenata}

Analiza silabusa za Školsku pedagogiju na izabranim Filozofskim fakultetima $\mathrm{u}$ aspektu načina ocenjivanja studenata, pokazala je postojenje delimične usaglašenosti. Može se konstatovati da se uglavnom načini ocenjivanja svode na vrednovanje putem primene testova znanja, ocenjivanje samostalih radova studenata i njihovog aktivnog učešća u aktivnostima. Međutim, u odnosu na broj bodova koje studenti dobijaju na predispitnim aktivnostima, kao i na samom ispitu, prisutne su razlike. U silabusu za Školsku pedagogiju Filozofskog fakulteta u Skoplju, testovi znanja mogu nositi do 70 bodova, dok samostalni rad studenata (seminarski radovi, projekti, prezentacije, nose maksimalno 15 bodova, a aktivnost i učešće studenata može 
nositi maksimalno 15 bodova). U silabusu Filozofskog fakulteta u Nikšiću se navodi da se ocenjivanje zasniva na primeni dva testa znanja koji nose maksimalno po 20 poena, aktivnost na predavanjima i učešće u debatama može nositi 3 poena, napisani esej na zadatu temu 8 poena i završni ispit na kome se može dobiti maksimalno 49 poena. U silabusu za Školsku pedagogiju na Filozofskom fakultetu u Nišu navedeno je da se ocenjuju predispitne obaveze studenata, a studenti polažu i ispit koji je i pismeni i usmeni. Predispitne obaveze, koje mogu nositi maksimalno 50 poena su: aktivnost $u$ toku predavanja do 5 poena; prezentacija projekata do 10 poena, test znanja do 20 poena i seminarski rad do 15 poena. Ispit se sastoji od pisanog dela koji može nositi do 12 poena i usmenog dela ispita sa maksimalno 30 poena. $U$ domenu načina ocenjivanja, analiza silabusa je pokazala da se načini ocenjivanja razlikuju, da je veća usaglašenost u načinima ocenjivanja predispitnih obaveza, dok su kod ocenjivanja na ispitima prisutne razlike. Dok u silabusima za predmet Školska pedagogija na Filozofskom fakultetu u Skoplju studenti mogu samo na osnovu testova da polože ispit, na Filozofskim fakultetima u Nikšiću i Nišu obavezno je polaganje završnog ispita. Razlika je i u tome što se jedino na Filozofskom fakultetu u Nišu ispit iz predmeta Školska pedagogija polaže i pismeno i usmeno.

\subsection{Ishodi učenja}

$\mathrm{U}$ domenu ishoda učenja usaglašenost $u$ analiziranim silabusima za predmet Školska pedagogija prisutna je na Filozofskim fakultetima u Skoplju, Nikšiću i Nišu. Na Filozofskom fakultetu u Skoplju ishodi učenja su objedinjeni sa ciljevima predmeta i šire definisani: da studenti steknu osnovna znanja o tradicionalnim i savremenim modelima pedagoške delatnosti u školi i o faktorima i nosiocima vaspitnoobrazovne delatnosti, kao i da se osposobe za planiranje, realizaciju i vrednovanje pedagoškog rada u školi. Na Filozofskom fakultetu u Nikšiću ishodi učenja su mnogo konkretnije definisani. Naime, u ovom silabusu se navodi da će nakon položenog ispita student biti u mogućnosti da: Opiše i objasni osnovne pojmove i teorije školske pedagogije; Analizira školski sistem i mesto škole u tom sistemu; Objasni postanak i razvoj škole, krizu i kritiku škole, kao i alternativne škole; Imenuje strukturu vaspitno-obrazovne delatnosti škole; Poveže i obrazloži ulogu učenika i nastavnika u školi; Razlikuje demokratske od etatističkih vidova upravljanja školom. U silabusu za predmet Školska pedagogija na Filozofskom fakultetu u Nišu nakon položenog ispita očekuje se: Razvoj profesionalnih kompetencija u oblasti vaspitno-obrazovnog rada u školi; Razvoj kritičkog mišljenja o aktuelnim problemima u školi u cilju ispitivanja, menjanja i razvoja školske prakse; Razvoj sposobnosti argumentovane diskusije, izlaganja i prezentacije.

\subsection{Predviđena literatura}

Najveće razlike u analiziranim silabusima za predmet Školska pedagogija prisutne su u delu literature koja se koristi za realizaciju sadržaja predmeta. Interesantno je da u sadržajima predmeta postoji velika usaglašenost, odnosno da se izučavaju iste ili slične teme, dok je literatura za pripremanje ispita u svim slilabusima 
različita. Sličnosti se nalaze u popisu literature u silabusima za Školsku pedagogiju u Skoplju i Nikšiću, gde se u oba popisa navodi zbirka tekstova Školska pedagogija (Ilić i sar., 2008); kao i u silabusima Filozofskog fakulteta u Nikšiću i Nišu, gde je takođe, reč samo o jednoj knjizi - Školska pedagogija I i II (Trnavac, 2005). Shodno tome može se zaključiti da su najznačajnije razlike u silabusima za predmet Školska pedagogija na Filozofskom fakultetu u Skoplju, Nikšiću i Nišu prisutne na nivou predložene literature.

\section{Zaključak}

Na osnovu podataka dobijenih uporednom analizom može se zaključiti da je osnovna hipoteza istraživanja da postoji usaglašenost u silabusima predmeta Školska pedagogija na Filozofskom fakultetu Univerziteta u Skoplju, Nikšiću i Nišu delimično potvrđena. Istraživanje je pokazalo da u odnosu na jedinice analize postoje razlike i da stepen usaglašenosti sadržaja silabusa za predmet Školska pedagogija varira u odnosu na pojedine jedinice analize. Visok stepen saglasnosti prisutan je kod određivanja ciljeva i sadržaja predmeta, što je i očekivano, posebno ako se ima $\mathrm{u}$ vidu da je u svim silabusima na veoma sličan način definisan cilj i da sadržaji predmeta čine temeljna znanja iz oblasti Školske pedagogije. Za razliku od toga, primetno je da postoje razlike kod pojedinih jedinica analize, poput načina ocenjivanja koje se kreće od mogućnosti da se ispit položi samo kroz uspešno urađene predispitne obaveze do načina polaganja u kome se od studenata zahteva da pored uspešno urađenih predispitnih aktivnosti, ispit polažu i pismeno i usmeno.

Najniži stepen usaglašenosti je uočen kod jedinice analize koja se odnosila na literaturu koja je neohodna za pripremanje i polaganje ispita, što se može tumačiti društveno-kulturološkom uslovljenošću odabira literature. Dakle, prevashodno se predlaže literatura na studentima bliskom jeziku.

Premda je u ovom radu prikazana analiza za samo jedan studijski predmet, što je svakako značajno ograničenje, ipak rezulatati dobijeni istraživanjem mogu biti korisni, pre svega zbog sticanja uvida vezanog za pozicioniranje Školske pedagogije kao studijskog predmeta u studijskim programima za pedagogiju u zemljama u okruženju. Osim toga, rezultati istraživanja mogu biti osnova za promene u silabusu za predmet Školska pedagogija u narednoj reakreditaciji studijskog programa za pedagogiju na Filozofskom fakultetu u Nišu.

\section{Literatura}

Đorđević, M. i Ničković, R. (1991). Pedagogija. Niš: Prosveta.

Havelka, N. (2000). Učenik i nastavnik u obrazovnom procesu. Beograd: Zavod za udžbenike i nastavna sredstva.

Hebib, E. (2009). Škola kao sistem. Beograd: Institut za pedagogiju i andragogiju Filozof- 
skog fakulteta u Beogradu.

Ikor, R. (1980). Škola i kultura. Beograd: BIGZ.

Ilić, M., Nikolić, R. i Jovanović, B. (2008). Školska pedagogija. Banja Luka: Filozofski fakultet.

Индикатори за квалитет за развој на училиштата. (2009). Скопје: Министерство за образование и наука. Државен просветен инспекторат.

Janković, P. i Rodić, R. (2007). Školska pedagogija (prilozi). Sombor: Pedagoški fakultet u Somboru, Centar za izdavačku delatnost.

Jorgensen, M. (1977). Škola koju su osnovali učenici. Beograd: BIGZ.

Janković, P. i Rodić, R. (2007). Školska pedagogija, Sombor: Učiteljski fakultet.

Kačapor, S. i Vilotijević, N. (2005). Školska i porodična pedagogija. Beograd, Kosovska Mitrovica: Filozofski fakultet u Kosovskoj Mitrovici, Učiteljski fakultet u Beogradu.

Krneta, Lj., Potkonjak, N., Schmit, V. i Šimpleša, P. (1968). Pedagogija II . Zagreb: Matica Hrvatska.

Leksikon obrazovnih termina (2014). Beograd: Učiteljski fakultet.

Marković, M. i Stanisavljević Petrović, Z. (2017). Školska pedagogija kao studijski predmet na visokoškolskim ustanovama u Srbiji. U: B. Dimitrijević (ur.). Nauka i savremeni univerzitet - NISUN 6. I tom (497-509). Niš: Filozofski fakultet.

Pedagoška enkciklopedija 2 (1989). Beograd: Zavod za udžbenike i nastavna sredstva.

Pedagoški leksikon (1996). Beograd: Zavod za udžbenike i nastavna sredstva.

Петковски, К. и Трајковска, И. (2004). Прирачник за развојно планирағе на училиштето. Битола: Херакли-Комерц.

Петковски, Н. К. и Алексова А. М. (2004). Водење на динамично училиште. Скопје: биро за развој на образованието.

Roeders, P. (2003). Interaktivna nastava. Beograd: Institut za pedagogiju i andragogiju Filozofskog fakulteta.

Stanisavljević Petrović, Z. i Vidanović, D. (2012): Promene u školskom sistemu u Srbiji. Niš: Filozofski fakultet.

Стојановска, В. (2017). Училишна педагогија (интерна скрипта). Скопје: Филозофски факултет.

Студијска и предметна програма по Педагогија од I (прв) ичиклус на студии на Филозофски факултет, 2018/2019.

Trnavac, N. i Đorđević, J. (1992). Pedagogija. Beograd: Naučna knjiga.

Trnavac, N. (2005). Školska pedagogija I i II. Beograd: Naučna knjiga - komerc.

Vilotijević, M. (1993). Organizacija i rukovođenje školom. Beograd: Naučna knjiga.

Vrcelj, S. (2000). Školska pedagogija. Rijeka: Filozofski fakultet.

Internet izvori:

https://www.ucg.ac.me/predmet/19/29/0/0/14-skolska-pedagogija

https://drive.google.com/file/d/1yYSHkYsKTcd0Hj0E7ewRJvTejxmt9Ues/view

https://drive.google.com/drive/u/0/folders/1CLpZfXwdNPuvK16y1b_iGoue8Pzbgwa0 


\title{
SCHOOL PEDAGOGY IN STUDY PROGRAMS OF BASIC ACADEMIC STUDIES OF PEDAGOGY - ANALYSIS OF SYLLABUSES
}

\author{
Zorica Stanisavljević Petrović, Marija Marković, Anastasija Mamutović \\ University of Niš, Faculty of Philosophy, Department of Pedagogy
}

\begin{abstract}
The paper presents a comparative analysis of the syllabuses of the academic subject School Pedagogy in the study programs of pedagogy at Faculty of Philosophy in Niš, Nikšić and Skopje. The aim of this paper was to examine the syllabuses compliance for the existing School pedagogy courses at the basic academic studies of pedagogy at the mentioned faculties. The content analysis was used as a basic research technique for the analysis of syllabuses for School pedagogy as an academic course. Comparative analysis was done on the basis of the following units of analysis: course status, objectives, course content, teaching and learning methods, method of assessment, learning outcomes and literature. The research results show that there are differences in the examined units of analysis and that the degree of compliance of the content of the syllabuses for School pedagogy course varies across the examined areas. The highest level of compliance was found in the domain of objectives and content of the course, while the lowest level of compliance was perceived in the domain of literature. The implications of the research could be the basis for the changes in the syllabus for the School pedagogy course in the next re-accreditation of the study program of pedagogy at the Faculty of Philosophy in Niš.
\end{abstract}

Key words: school pedagogy, study programs, syllabuses, compliance, analysis.

\section{Citiranje članka:}

Stanisavljević Petrović, Z., Marković, M. i Mamutović, A. (2019). Školska pedagogija u studijskim programima osnovnih akademskih studija pedagogije - analiza silabusa. Godišnjak za pedagogiju, 4(1), 47-59 
